\title{
PENGUATAN KEARIFAN LOKAL BERBASIS BUDAYA MELALUI PENDIDIKAN KARAKTER PADA ANAK SEKOLAH DI DESA TENGANAN PAGRINGSINGAN KABUPATEN KARANGASEM
}

\author{
Oleh \\ Ni Nyoman Metri; I Nyoman Sueca \\ SDN 3 Kedisan, Tegallalang; Universitas Hindu Negeri I Gusti Bagus Sugriwa Denpasar \\ metrininyoman66@gmail.com ; inyomansueca64@gmail.com
}

\begin{abstract}
Potential growth in school children is carried out by teachers through character education by preserving local wisdom. Local wisdom is an intelligence possessed by certain ethnic groups, which is obtained through the experience of the ethnic struggling with their environment, Haryono (in Gunawan, 2015:17). When a society adapts to its environment, they develop a good wisdom in the form of knowledge or ideas, tools, combined with customary norms, cultural values, activities to manage the environment to meet the needs of their lives. Local wisdom is the result of a process of adaptation from generation to generation in a very long period of time to a natural environment in which to live. Local wisdom is generally in the form of oral and written in a social system of society. Local wisdom is closely related to geographical conditions or the natural environment with values that can be the main capital in building a community, with the characteristics of local wisdom including the ability to withstand external culture, to accommodate external cultural elements, to integrate elements of foreign culture into indigenous culture, to control culture, and to provide direction to cultural development. The strengthening of local wisdom in Tenganan Pagringsingan can be sustainable until now based on non-formal early character education, where parents in the villages of Tenganan Pagringsingan Banjar Kauh and Banjar Tengah have educated their children through speech and messages. which refers to the awig-awig of the traditional village of Tenganan where in the awig-awig there is an order that regulates the social life of the local community and sanctions against violations of the awig-awig.
\end{abstract}

Keywords: Reinforcing culture-based local wisdom.

\section{Abstrak}

Pertumbuhan potensi pada anak sekolah dilakukan guru melalui pendidikan karakter dengan melestarikan kearifan lokal. Kearifan lokal merupakan sebuah kecerdasan yang dimiliki oleh kelompok etnis tertentu, yang diperoleh melalui pengalaman etnis tersebut bergulat dengan lingkungan hidupnya Haryono (dalam Gunawan, 2015:17). Ketika sebuah masyarakat melakukan adaptasi terhadap lingkungannya, mereka mengembangkan sebuah kearifan baik yang berwujud pengetahuan atau ide, peralatan, dipadu dengan dengan norma adat, nilai budaya, aktivitas mengelola lingkungan guna mencukupi kebutuhan hidupanya.

Penguatan Kearifan Lokal Berbasis Budaya Melalui Pendidikan Karakter Pada Anak Sekolah Di Desa Tenganan Pagringsingan Kabupaten Karangasem

SDN 3 Kedisan, Tegallalang; Universitas Hindu Negeri I Ni Nyoman Metri; I Nyoman Sueca

Gusti Bagus Sugriwa Denpasar 
Kearifan lokal merupakan hasil dari proses adaptasi secara turun temurun dalam periode yang sangat lama terhadap suatu lingkungan alam tempat tinggal. Kearifan lokal umumnya berbentuk lisan dan tulisan dalam suatu system sosial masyarakat. Kearifan lokal berkaitan erat dengan kondisi geografis atau lingkungan alam dengan nilai yang dapat menjadi modal utama dalam membangun masyarakat, dengan ciri-ciri kearifan lokal di antaranya adalah adanya kemampuan-kemampuan untuk bertahan terhadap budaya dari luar, untuk mengakomodasikan unsur-unsur budaya luar, untuk mengintegrasikan unsur-unsur budaya luar kedalam budaya asli, untuk mengendalikan budaya, dan untuk memberikan arah ke perkembangan budaya. Penguatan kearifan lokal yang ada di Tenganan Pagringsingan bisa lestari sampai saat ini didasari pada pendidikan karakter sejak dini yang bersifat nonformal, dimana para orang tua yang ada di desa Tenganan Pagringsingan Banjar Kauh dan Banjar Tengah sudah mendidik anak-anak mereka melalui tutur dan pesan-pesan yang mengacu pada awig-awig desa adat Tenganan dimana dalam awig-awig tersebut terdapat tatanan yang mengatur kehidupan sosial masyarakat setempat dan sangsi terhadap pelanggarana awig-awig tersebut.

Kata kunci: Penguatan kearifan lokal berbasis budaya

\section{PENDAHULUAN}

Krisis moral masih menjadi persoalan yang sangat serius bagi bangsa Indonesia. Berbagai berita, baik yang dirilis media cetak maupun elektronik, mewartakan semakin merosotnya moralitas anak bangsa, hal ini bisa kita lihat dengan maraknya perkelahian atau tawuran antar kampung, mahasiswa dan siswa seperti sudah membudaya. Selain tawuran, tren pergaulan tanpa batas yang dibarengi seks bebas, bagi sebagian oknum anak bangsa sudah menjadi hal biasa. Disisi lain budaya kekerasan tidak hanya berasal dari anak didik, tetapi juga dari lingkungan lain mengenai mereka. Dalam hal ini anak-anak sekolah menjadi korban. Untuk meminimalisasikan segala bentuk kekerasan yang ada di masyarakat, peran orang tua dan keluarga sangat dominan untuk mencegah segala bentuk kekerasan demi kenyamanan anak-anak sekolah.

Idialnya keluarga menjadi tempat perlindungan yang aman dan nyaman bagi anak-anak. Sedangkan sekolah menjadi tempat di mana anak-anak bisa menjalani proses penumbuhkembangan dan memupuk aneka potensi mereka dengan penuh keceriaaan dan kegembiraan. Semestinya, orang tua siswa merasa tenang menitipkan buah hatinya tanpa ada rasa was-was dan kekhawatiran.

Penumbuhkembangan potensi anakanak sekolah dapat dilakukan oleh guru melalui pendidikan karakter dengan memperkuat kearifan lokal. Kearifan lokal merupakan sebuah kecerdasan yang dimiliki oleh kelompok etnis tertentu, yang diperoleh melalui pengalaman etnis tersebut bergulat dengan lingkungan hidupnya Haryono (dalam Gunawan, 2015:17). Dan juga kearifan local merupakan sebuah warisan nenek moyang yang berkaitan dengan tata nilai kehidupan Suhartini (dalam Wibowo, 2015: 23). Tata nilai kehidupan ini menyatu tidak hanya di dalam bentuk relegi, tetapi juga dalam budaya, dan adat istiadat. Ketika sebuah masyarakat melakukan adaptasi terhadap lingkungannya, mereka mengembangkan sebuah kearifan baik yang berwujud pengetahuan atau ide, peralatan, dipadu dengan dengan norma adat, nilai budaya, 
aktivitas mengelola lingkungan guna mencukupi kebutuhan hidupanya.

Hakekat kearifan lokal menurut Undang-Undang Nomor 32 Tahun 2009 adalah nilai-nilai luhur yang berlaku dalam tata kehidupan masyarakat. Nilai-nilai luhur tersebut di antaranya untuk melindungi dan mengelola lingkungan hidup secara lestari. Kearifan lokal merupakan hasil dari proses adaptasi secara turun temurun dalam periode yang sangat lama terhadap suatu lingkungan alam tempat tinggal. Kearifan lokal umumnya berbentuk lisan dan tulisan dalam suatu system sosial masyarakat. Kearifan lokal berkaitan erat dengan kondisi geografis atau lingkungan alam dengan nilai yang dapat menjadi modal utama dalam membangun masyarakat.

Ciri-ciri kearifan lokal di antaranya adalah adanya kemampuan-kemampuan untuk bertahan terhadap budaya dari luar, untuk mengakomodasikan unsur-unsur budaya luar, untuk mengintegrasikan unsurunsur budaya luar kedalam budaya asli, untuk mengendalikan budaya, dan untuk memberikan arah ke perkembangan budaya. Adapun fungsi kearifan lokal adalah sebagai konservasi nilai warisan dan pelestarian sumber daya alam, untuk mengembangkan sumber daya manusia, dan untuk pengembangan kebudayaan serta ilmu pengetahuan dan nilai-nilai luhur untuk melindungi dan mengelola lingkungan hidup sebagai karakter luhur.

Salah satu karakter luhur yang wajib diinternalisasikan terhadap anak-anak didik menurut Kemdikns (2010) adalah peduli lingkungan. Karakter peduli lingkungan merupakan sikap dan tindakan yang selalu berupaya mencegah kerusakan pada lingkungan alam disekitarnya, dan mengembangkan upaya-upaya untuk memperbaiki kerusakan alam yang sudah terjadi.

Salah satu karakter luhur yang terjadi dalam budaya masyarakat yang ada di desa Tenganan Pagringsingan Karangasem terdapat kearifan lokal terkait dengan adat istiadat salah satunya perkawinan, yang paling ngetren dan merupakan tontonan pariwisata adalah acara mageret pandan yang dilaksanakan setiap sasih kelima "wawancara dengan Ketut Pancawan selaku stap Kebendesaan pada tanggal 27 Januari 2019”. Dalam penelitian ini peneliti melihat ke unikkan yang dilakukan oleh masyarakat Tenganan Banjar Tengah dan Banjar Kauh adalah perkawinan masyarakat lokal dengan orang luar yang bersetatus janda. Pada saat masyarakt lokal menikahi seorang isti dari luar desa Tenganan yang berstatus janda, mereka akan dibuang ke Banjar Pande, sehingga Banjar pande sampai saat ini disebuat Banjar Buangan.

Kebertahanan dalam sebuah tradisi lokal bisa dilakukan masa anak-anak yang merupakan masa yang menyenangkan. Anakan-anak akan merasa gembira ketika bertemu, berkumpul dengan anak yang seusia pada tempat yang telah tersedia oleh masyarakat. Dilingkungan desa adat Tenganan mereka bertemu di bale panjang yang ada di tengah-tengah desa untuk di didik oleh para tokoh masyarakat untuk dapat mempertahankan tradisinya sebagai sebuah kearifan lokal.

Sampai saat ini permasalahan di desa Tenganan Karangasem terkait dengan penguatan kearifan lokal masih tetap bertahan, sehingga pendidikan karakter nonformal sangat di perlukan disamping juga pendidikan karakter yang di peroleh di sekolah formal, karena sekolah belum menjamin mampu akan mengatasi keseluruhan pendidikan karakter mengingat 
waktu yang tersedia di sekolah cukup terbatas. Disamping itu pendidikan informal adalah pendidikan yang utama dalam membentuk pendidikan karakter pada anak menuju pendidikan formal.

Dari hasil observasi awal, minggu 27 Januari 2019, di Banjar Kauh desa Tenganan dengan Bapak Ketut Pancawan selaku stap kebendesa diketahui bahwa "kuatnya untuk mempertahankan budaya dan adat istiadat dan kemampuan bertahannya terhadap budaya luar didasari atas tertanamnya nilai-nilai luhur dalam tata kehidupan sebagai masyarakat, merupakan wujud pendidikan karakter". Prinsip dasar pendidikan karakter, dimana sekolah merupakan sebuah lembaga yang dapat menjaga kehidupan nilai-nilai sebuah masyarakat. Oleh karena itu, bukan sembarang cara bertindak, pola perilaku yang diajarkan di dalam sekolah, melainkan nilainilai yang semakin membawa proses membudayakan dan manusialah yang boleh masuk di dalam menanamkan di sekolah.

Penguatan kearifan lokal di desa Tenganan Pagringsingan disampin juga merupakan desa tatanan masyarakatnya yang tradisional, desa Tenganan juga merupakan basis desa pariwisata. Pengembangan desa pariwisata di daerah desa Tenganan telah banyak menghasilkan kemajuan, hal ini sudah terbukti pariwisata yang berkembang pesat sampai di daerah Candi Dasa. Untuk menjadikan desa Tenganan sebagai desa destinasi wisata yang dapat melibatkan publik dan juga berdampak kepada masyarakat, maka itu bukan segampang membalikan telapak tangan, tetapi harus dapat mengembangkan beberapa aspek antara lain; (a) attraction (daya tarik), b) accesabilyty (aksessibilitas), c) amnessitas (fasilitas), dan d) ancillary (kelembagaan). Oleh karena itu dalam rangka membangun desa-desa wisata di desa Tenganan, hendaknya empat aspek itu perlu diperhatikan dan dapat dikembangkan dengan baik.

Konsep pengembangan pariwisata di desa Tenganan, perlu dikembangkan melalui aspek adat dan tradisi lokal maupun tatanan kehidupan social masyarakat yang tradisional. Dengan demikian penguatan budaya sebagai kearifan lokal perlu dikembangkan melalui penanaman pendidikan karakter pada anak sekolah, karena anak sekolah adalah masa mengisi sesuatu pada mereka untuk menjadikan anak yang mandiri, berbudi, cerdas dan terampil, sehingga mampu bertanggungjawab.

Desa Tenganan sejak awal sudah memiliki tradisi yang cukup terkenal di mata pariwisata salah satunya adalah kain tenun pagringsingan, mageret pandang dan keunikan pada perkawinanya yang hidup dan berkembang sepanjang hidup masyarkatnya. Dengan demikian pengembangan produk wisata mageret pandan dan kain tenun pagringsingan merupakan salah satu produk budaya masyarakat Tenganan yang berpotensi untuk dikembangkan sebagai produk di setiap desa wisata berbasis budaya.

Sementara yang diharapkan masyarakat setempat adalah kearipan lokal yang merupakan warisan luhur yang berkaitan erat dengan tata nilai kehidupan. Tata nilai kehidupan ini menyatu tidak hanya dalam bentuk relegi, tetapi juga dalam bentuk budaya dan adat istiadat. Warisan leluhur sebagai kearifan lokal hendaknya dipertahankan melalui pendidikan karakter yang dilakukan oleh orang tua maupun tokoh masyarakat dan dilanjutkan pada pendidikan formal.

Fenomena di lapangan saat ini menunjukkan bahwa penguatan kearifan lokal berbasis budaya masih eksis, namun pengaruh globalisasi tidak akan bisa terhindar, hal ini terbukti dalam pergaulan orang-orang 
remaja yang telah bekerja di luar desanya secara otomatis sudah kena pegaruh luar untuk masuk kedesa setempat yang mampu akan berkalaborasi dalam budaya setempat, sehingga dari tatanan kehidupan sosialnya tidak seperti jaman dahulu. Untuk kuatnya suatu kearifan lokal atau tradisi maka penanaman nilai-nilai kehidupan dapat dilakukan melalui pendidikan karakter.

Hal ini dapat dijadikan salah satu indikasi untuk menunjukkan penguatan kearifan lokal berbasis budaya mesti dipertahankan melalui pendidikan karakter. Delapan belas (18) nilai karakter yang hendaknya ditanamkan di dalam diri peserta didik sebagai upaya membangun karakter anak sekolah atau karakter bangsa, sehingga penguatan kearifan lokal akan menjadi original.

\section{METODE}

Metode penelitian pada dasarnya merupakan cara ilmiah untuk mendapatkan data dengan tujuan dan kegunaan tertentu (Sugiyono, 2017). Cara ilmiah mempunyai karakteristik seperti; rasional, empiris, dan sistematis. Metode kualitatif juga sering disebut metode penelitian naturalistik, karena penelitiannya dilakukan pada kondisi yang alamiah (natural setting) (Sugiyono, 2007: 78). Dalam penelitian lapangan ini, ada beberapa metode dipergunakan dalam menunjang proses penelitian atau jalannya penelitian, mulai dari persiapan, pelaksanaan sampai penelitian berakhir dan menghasilkan suatu karya ilmiah yang diakui kebenarannya. Melalui penelitian manusia dapat mengunakan hasilnya. Secara umum data yang telah diperoleh dari penelitian dapat digunakan untuk memahami, memecahkan dan mengantisipasi masalah.

\section{Data}

Jenis data yang dikumpulkan dalam penelitian ini adalah, jenis data kualitatif dan didukung data kuantitatif. Menurut Subagyo (2007: 87) menyatakan bahwa jenis data kualitatif diperoleh secara langsung dari masyarakat baik yang dilakukan melalui wawancara, observasi dan alat lainnya merupakan data primer, sedangkan jenis data yang diperoleh dari atau berasal dari bahan kepustakaan disebut data sekunder.

Data kualitatif adalah data yang dinyatakan bukan dalam bentuk angka-angka, melainkan dalam bentuk kalimat, pernyataan, atau uraian yang bersumber dari informan, seperti, tokoh adat, tokoh agama desa Tenganan dan beberapa anak sekolah.

\section{Metode Analisis Data}

Data yang telah terkumpul bersumber dari hasil; observasi, wawancara, dan dokumentasi masih dalam bentuk mentah, maka selanjutnya data akan dipilih dan dipilah, kemudian akan disajikan menggunakan kalimat-kalimat dan terakhir dilakukan penyimpulan.

Menurut Miles dan Huberman (1992), teknik analisis data yang cocok digunakan untuk jenis deskriptif adalah taktik deskriptif melalui tiga alur kegiatan, yaitu (1) reduksi data, (2) penyajian data, dan (3) penarikan kesimpulan atau verifikasi. Ketiga alur kegiatan ini saling berkaitan dan merupakan alat analisis yang memungkinkan data menjadi bermakna.

\section{PEMBAHASAN}

Bentuk penguatan kearifal lokal berbasis budaya melalui pendidikan karakter pada anak sekolah. Bentuk penguatan kearifan lokal antara lain: gotong royong, keteladanan, profesioal, dan kemandirian. Gotong royong adalah usaha bersama yang dilakukan tokoh masyarakat dalam mencapai tujuan mempertahankan nilai-nilai kearifan lokal yang berbasis budaya. Gotong royong 
merupakan kerja sama timbul saat seseorang menyadari bahwa mereka punya kepentingan bersama. Kerja sama menuntut adanya tujuan yang ingin dicapai, dengan baik. Kerja sama akan bertambah kuat bila ada tantangan yang amat berat yang mesti diberikan solusi. Bentuk penguatan dalam gotong royong seperti; kerukunan, loyalitas, adanya rasa memiliki.

Keteladanan merupakan cara yang bisa dilakukan tokoh agama dan tokoh masyarakat dalam memberikan pembinaan untuk menguatan kearifan lokal sebagai sebuah nilai-nilai kehidupan masyarakat yang diatur dalam sebuah awig-awig. Keteladanan masyarakat adalah "leadingby exampk; being a model, role modeling" (berperan sebagai teladan). Tokoh masyarakat dan tokoh agama yang menjalankan peran keteladanan menjadi simbol yang nyata atas apa yang mereka harapkan untuk diraih pengikutnya.

Profesional, merupakan bentuk penguatan dalam membina anak sekolaht melalui memelihara, merawat, melatih, mengajar, menuntun, membimbing, dan memimpin dalam mempertahankan kearifan lokalnya. Namun masyarakat yang dimaksud di sini adalah sosok manusia bergelar sebagai panutan, yang dalam berbagai bidang memiliki kelebihan dan keistimewaan karena telah memiliki kualifikasi sebagai tokoh agama dan tokoh masyarakat.

Kemandirian merupakan sikap atau perilaku dan mental yang memungkinkan tokoh agama dan tokoh masyarakat untuk bertindak dalam melakukan pembinaanpembinaan di masyarakat secara bebas, dan bermanfaat, dengan berusaha melakukan sesuatu dengan jujur, benar atas dorongan dirinya sendiri, sesuai dengan tugas dan kewajibannya sebagai tokoh masyarakat, sehingga dapat memberikan pembinaan yang sangat bermanfaat bagi kehidupan anak sekolah yang ada di desa Tenganan Karangasem. Ciri-ciri kemandirianantara lain; (1) memiliki kemampuan untuk selalu berusaha dan memiliki inisiatif, (2) memilki kemampuan untuk melaksanakan tugas dan tanggungjawab, dan (3) memilki kemampuan untuk menyelesaikan segala permaslahan yang ada di masyarakat.

Proses penanaman nilai-nilai karater pada anak yang dilaksanakan tokoh masyarakat dan tokoh agama dilakukan dengan konsep ajaran agama Hindu berbasis masyarakat yang terdapat dalam ajaran Tri Hita Karana. Adapun tujuannya adalah untuk meningkatkan sradha bhakti dan menanamkan niali-nilai moral, serta memperkuat kearifan lokal yang berbasis budaya sebagai warisan para leluhurnya.

Penanaman nilai-nilai karakter pada anak sekolah dinilai sangat penting dalam upaya meningkatkan kualitas pendidikan agama dan pendidikan keagamaan Hindu serta mengubah prilaku sumber daya manusia, sehingga menjadi lebih dinamis, eksploratif dalam meningkatkan pengetahuan dan pengalaman hidup serta mengembangkan desa yang berbasis pada pariwisata.

\section{SIMPULAN}

Penguatan kearifan lokal lestari sampai saat ini terpuast pada pendidikan karakter yang bersifat nonformal, dimana para orang tua yang ada di desa Tenganan Pagringsingan Banjar Kauh dan Banjar Tengah sudah mendidik anak-anak mereka melalui tutur dan pesan-pesan yang mengacu pada awig-awig desa adat Tenganan dimana dalam awig-awig tersebut terdapat tatanan yang mengatur kehidupan sosial masyarakat setempat dan sangsi terhadap pelanggarana awig-awig tersebut.

Penguatan kearifan lokal di desa Tenganan Pagringsingan disampin juga desa 
tatanan tradisional, desa Tenganan juga merupakan basis desa pariwisata. Pengembangan desa pariwisata di daerah desa Tenganan telah banyak menghasilkan kemajuan, hal ini sudah terbukti pariwisata yang berkembang pesat sampai di daerah Candi Dasa. Untuk menjadikan desa Tenganan sebagai desa destinasi wisata yang dapat melibatkan publik dan juga berdampak kepada masyarakat, maka itu bukan segampang membalikan telapak tangan, tetapi harus dapat mengembangkan beberapa aspek antara lain; (a) attraction (daya tarik), b) accesabilyty (aksessibilitas), c) amnessitas (fasilitas), dan d) ancillary (kelembagaan). Oleh karena itu dalam rangka membangun desa-desa wisata di desa Tenganan, hendaknya empat aspek itu perlu diperhatikan dan dapat dikembangkan dengan baik.

Bentuk penguatan kearifal lokal berbasis budaya melalui pendidikan karakter pada anak sekolah dapat dilakukan melalui sikap gotong royong, keteladanan, profesioal, dan kemandirian. Proses penanaman nilai-nilai karakter pada anak sekolah untuk menguatkan kearifan lokal. Proses penanaman nilai-nilai karater pada anak yang dilaksanakan tokoh masyarakat dan tokoh agama dilakukan dengan konsep ajaran agama Hindu berbasis masyarakat yang terdapat dalam ajaran Tri Hita Karana.

\section{DAFTAR PUSTAKA}

Alfian. 1980. Politik, Kebudayaan dan Manusia Indonesia. Jakarta: LP3S.

Agus Wibowo. 2012. Pendidikan Karakter Usia Dini. Strategis Membangun Karakter Di Usia Emas. Yogyakata: Pustaka pelajar.

Ery Iswari. 2017. Jurnal mengkaji Orientasi Pendidikan Karakter Berbasis Kearifan Lokal Makasar.
Gunawan, Wibowo. 2015. Pendidikan Karakter Berbasis Kearifan Lokal di Sekolah.Yogyakarta: Pustaka Pelajar.

Haberman, A.M \& Miles, M.B. 1992. Model Analisi interaktif. Beverly Hills: SAGE Publikations, Inc

Sugiyono. 2017. Metode Penelitian Kuantitatif Kualitatif Dan $R \& D$. Bandung: Alfabeta.

Subagyo. 2007. Metode Penelitian Pendidikan dan Pengembangan. Jakarta: Prenadamedia Group.

Sulistianingsih. 2017. Jurnal mengkaji Nilainilai Kearifan Lokal Jawa dalam Pembentukan Hukum.

Suarta. 2012. Jurnal mengkaji Membangun Pendidikan Karater Kearifan lokal.

Setyosari Punaji. 2016. Metode Penelitian Pendidikan dan Pengembangan. Jakarta: Prenadamedia Group. 